
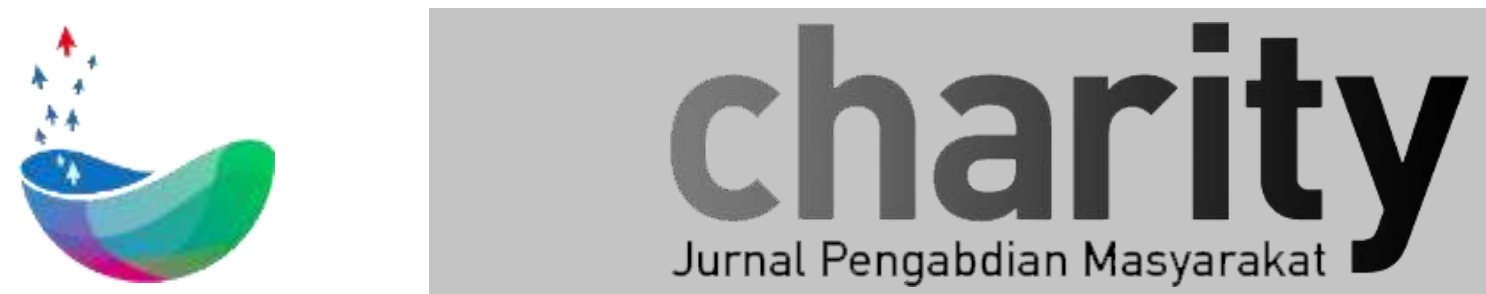

\title{
RINTISAN PEMBUATAN BANK SAMPAH BERBASIS KELOMPOK RUMAH TANGGA (RT) di RW-05 KELURAHAN CIPAGANTI, KECAMATAN COBLONG - KOTA BANDUNG
}

\author{
Ratna Lubis Nugroho ${ }^{1}$, Astri Ghina ${ }^{2}$, Sisca Eka Fitria ${ }^{3}$ \\ ${ }^{1}$ Fakultas Ekonomi dan Bisnis (FEB), Universitas Telkom Bandung \\ ${ }^{2}$ Fakultas Ekonomi dan Bisnis (FEB), Universitas Telkom Bandung \\ ${ }^{3}$ Fakultas Ekonomi dan Bisnis (FEB), Universitas Telkom Bandung \\ *ratnalnugroho@telkomuniversity.ac.id
}

\section{INFO ARTIKEL}

Diterima 1 November 2017

Direvisi 6 November 2017

Disetujui 16 November 2017

Tersedia Online 24 Oktober 2018
Keyword : potensi sampah, pengelolaan sampah, bank sampah

\begin{abstract}
ABSTRAK
Potensi sampah yang dihasilkan oleh 2,4 juta penduduk Kota Bandung dari berbagai aktivitas di lingkungan rumah tangga, institusi, kantor, rumah sakit, sekolah maupun kampus, adalahberkisar antara $1.500 \sim 1.600$ ton sampah per harinya. Tingginya produksi sampah yang belum diimbangi dengan pengelolaan ideal, berpotensi berdampak negatif pada aspek lingkungan dan kesehatan warga Bandung dan sekaligus juga semakin menambah beban Pemerintah Kota (Pemkot) Bandung.

Di sisi lain, persoalan tentang pengelolaan sampah masih terus berlanjut, yakni: (1) Pemkot Bandung belum menemukan solusi yang menyeluruh; (2) munculnya fenomena julukan "Bandung Lautan Api" yang kerap diplesetkan menjadi "Bandung Lautan Sampah"; (3) tidak imbangnya alat angkut sampah dengan volume sampah yang masuk ke berbagai tempat penampungan sampah;

(4) keterbatasan upaya Pemkot Bandung dalam mengatasi permasalahan pengelolaan sampah secara tepat dan berkelanjutan; (5) minimnya pemilahan sampah yang dilakukan oleh warga Kota Bandung yang dikhawatirkan akan berpotensi memicu kerusakan lingkungan; (6) kondisi lingkungan RW-05 Kelurahan Cipaganti di Jl.Cihampelas, Bandung yang berlokasi di bantaran sungai Cikapundung dan belum memiliki bank sampah berbasis kelompok Rumah Tangga (RT).

Selain bertujuan untuk memberikan solusi terhadap permasalahan sampah yang dialami Pemkot Bandung, Pengabdian kepada Masyarakat (PkM) ini juga bertujuan untuk mereduksi sampah di lingkungan RW-05 Kelurahan Cipaganti.
\end{abstract}

Korespondensi :

Direktorat Penelitian dan Pengabdian Masyarakat, Universitas Telkom

Jl. Telekomunikasi No. 1, Terusan Buah Batu, Bandung, 40257

Indonesia.

E-mail: charity@telkomuniversity.ac.id

ORCID ID:

Penulis Pertama: -

https://doi.org/10.25124/charity.v1i01.1580

Paper_reg_number Charity0008010108 @ The Authors. Published by Directorate of Research and Community

Service, Telkom University.

This is an open access article under the CC BY-NC 4.0 license (https://creativecommons.org/licenses/by-nc/4.0/) 


\section{PENDAHULUAN}

Eksistensi sampah di Kota Bandung selalu menjadi permasalahan rumit mulai dari persoalan kesehatan hingga isu sosial yang kerap menimbulkan konflik struktural antara pemerintah dan rakyat, yang disebabkan kurangnya pemahaman atau cara pandang masyarakat yang konvensional terhadap sampah. Masyarakat masih memandang sampah dari sisi negatif padahal tidak semua sampah harus dimusnahkan, melainkan cara pandang atau pemahaman yang harus dirubah, yakni melihat sampah sebagai bahan baku, produk ikutan yang masih dapat diolah dan merupakan sumber pendapatan yang potensial. Cara pandang atau pemahaman ini kerap dinyatakan dengan slogan "from trash to cash" atau "dari sampah menjadi berkah".

Meski berlabel "Kota Cerdas", menemukan solusi untuk permasalahan sampah di Kota Bandung bukan hal yang mudah. Saat Pemerintah Kota (Pemkot) Bandung masih mencari jalan terbaik, sejumlah masyarakat memilih mandiri menyelamatkan "Kota Kembang". Tanpa berharap pamrih mereka bergerak mandiri. Hal ini jugalah yang dilakukan oleh TimPengabdian kepada Masyarakat (PkM) dari Fakultas Ekonomi dan Bisnis (FEB) Universitas Telkom yang berkolaborasi dengan beberapa elemen masyarakat dengan melaksanakan kegiatan sosialisasi bank sampah sekaligus tukar sampah jadi sembako, yang sudah dilaksanakan pada tanggal 17 Januari 2017.

Pelaksanaan PkM dalam wujud kegiatan sosialisasi bank sampah sekaligus tukar sampah jadi sembako ini, sudah diliput oleh beberapa media cetak dan media elektronik, yang tentunya mengharumkan nama Fakultas Ekonomi dan Bisnis (FEB) dan juga nama Universitas Telkom. Berikut ini adalah paparan yang disajikan oleh wartawan Harian Pikiran Rakyat, yang diterbitkan pada edisi Kamis, 19 Januari 2017 di halaman-2.

\section{Yuk Biasakan Memilah Sampah}

HARIAN PIKIRAN

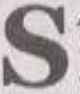

AMPAH menjadi masalah klasik

di hampir semua daerah, terutama daerah perkotaan dengan kepa-

datan penduduk tinggi seperti Kota Bandung.

Berbagai upaya, di antaranya sosialisasi pemilahan sampah dimulai dari rumah, terus dilakukan. Apalagi sampah rumah tangga tercatat sebagai penyumbang sampah terbesar selama ini.

Seperti yang dilakukan di RW 05 , Kelurahan Cipaganti, Kota Bandung, Selasa (17/1/2017). Sosialisusi bank sampah ini diselenggarakan atas kolaborasi tim peneliti dari Fakultas Ekonomi dan Bisnis (FEB) Telkom University, Gerakan

Masyarakat Cinta Cikapundung (Gemricik), Bank Sampah Bersinar, Komumitas Kehkel RW 05 Cihampelas, dan Karang Taruna Unit RW 05 Cihampelas.

"Yang paling penting dulam mengelola sampah adalah bagaimana mengubah perilaku masyarakat terhadap sampah agar memperlakukan sampah dengan cara yang bersahabat. Tidak lagi membuang sampah sembarangan," ujar Direktur Bank Sampah Bersinar (BSB) John Sumual.

Menurut John, penanganan sampah harus melibatkan warga. Jika tidak, sampai kapan pun persoalan sampah tak akan selesai. Anggapan sampah sebagai musuh dan sumber bencana harus diubah.

Warga dari delapan RT di RW 05 Kelurahan Cipaganti yang menghadiri acara tersebut tampak antusias. Mereka diberi tahu cara memilah sampah kering yang bisa ditabung di bank sampah, apa sija jenis-jenis sampah, hingga bagaimana mengubah sampah basah (organik) menjadi pupuk kompos.

Sulaeman (55), Seksi Lingkungan Hidup RW o5 mengaku senang dengan adanya sosialisasi bank sampah ini. "Alhamdulillah setelah presentasi warga terlihat antusias. Mudah-mudahan, kebersihan lingkungan di RW 05 ini jadi makin meningkat, dan warga juga semakin tahu bagaimana cara memilah sampah. Apalagi nanti ada keuntungannya," katanya. la mengatakan, RW 05 akan membentuk kelompok khusus untuk mengurus bank sampah. Tujuanuya agar misi memilah sampah dimulai dari rumah bisa terlaksana.

Ani Suryani (53), salah seorang warga, mengaku tertarik dengan bank sampah karena ternyata menguntungkan. "Insya Allah sedikit-sedikit mah ngerti tentang sampah. Ini juga karung -karung sampah (berisi plastik kemasun minuman) belum terkumpul semua. Cuma masalahnya

belum ada tempat buat mengelola bank sampah di sini," kata Ani.

Belum adanya bank sampah di RW 05 meniadi alasan Ketua Gemricik Ratna Nugroho berkolaborasi dengan beberapa pihak dalam kegiatan ini. Ratna yang juga peneliti dari FEB Telkom University ini mengaku program ini tak mudah serta perlu wuktu panjang. "Tidak mudah, contohnya adalah kami harus mengajak ibuibu yang ada di sini untuk bisa tahu seperti apa memilah sampah," katanya. (Nuryani/"PR)"*t

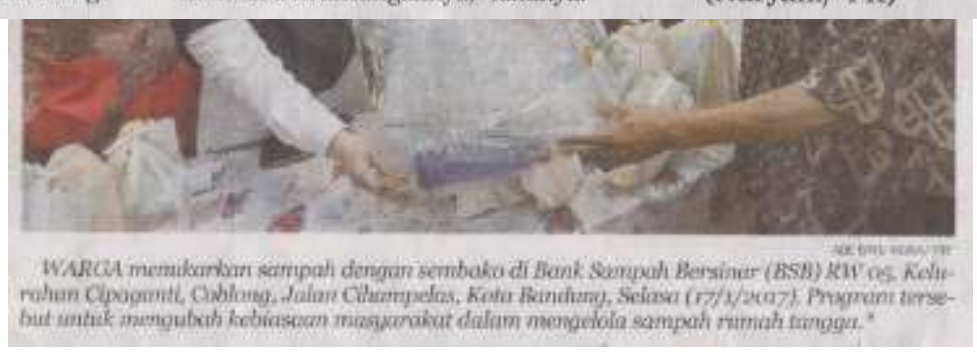


Tabel berikut ini menampilkan alamat tautan media elektronik yang meliput kegiatan Tim PkM dari Fakultas Ekonomi dan Bisnis (FEB) Universitas Telkom tersebut.

\begin{tabular}{|c|l|l|}
\hline No. & Nama Media & Alamat Tautan (web links) \\
\hline 1. & Pemrov Jabar & $\begin{array}{l}\text { http://www.jabarprov.go.id/index.php/news/20892/2017/01/17/Warga-RW-05- } \\
\text { Kelurahan-Cpaganti-Siap-Bangun-Bank-Sampah }\end{array}$ \\
\hline 2. & Pikiran Rakyat & $\begin{array}{l}\text { http://www.pikiran-rakyat.com/foto/2017/01/17/bank-sampah-bersinar-tukar- } \\
\text { sampah-dengan-sembako-390857 } \\
\text { http://www.pikiran-rakyat.com/bandung-raya/2017/01/19/bank-sampah-hadir-di- } \\
\text { cipaganti-391042 }\end{array}$ \\
\hline 3. & TEMPO & $\begin{array}{l}\text { https://store.tempo.co/foto/detail/P1701201700020/sosialisasi-bank-sampah-di- } \\
\text { bandung\#.WH7efVN96G4 }\end{array}$ \\
\hline 4. & TribunNews & $\begin{array}{l}\text { http://www.tribunnews.com/images/regional/view/1684872/sosialisasikan-bank- } \\
\text { sampah-tukar-sampah-dengan-sembako } \\
\text { http://www.tribunnews.com/images/regional/view/1684873/sosialisasikan-bank- } \\
\text { sampah-tukar-sampah-dengan-sembako\#img } \\
\text { http://www.tribunnews.com/images/regional/view/1684874/sosialisasikan-bank- } \\
\text { sampah-tukar-sampah-dengan-sembako\#img } \\
\text { http://www.tribunnews.com/images/regional/view/1684875/sosialisasikan-bank- } \\
\text { sampah-tukar-sampah-dengan-sembako }\end{array}$ \\
\hline 5. & Galamedia & $\begin{array}{l}\text { http://m.galamedianews.com/bandung-raya/131352/bank-sampah-dorong- } \\
\text { peningkatan-perekonomian-masyarakat.html }\end{array}$ \\
\hline 6. & Newswire & $\begin{array}{l}\text { http://newswire.id/content/warga-rw-05-kelurahan-cpaganti-siap-bangun-bank- } \\
\text { sampah }\end{array}$ \\
\hline
\end{tabular}

Berangkat dari kegiatan sosialisasi bank sampah sekaligus tukar sampah tersebut, maka Tim PkM yang sama mengajukan proposal multi tahun pada periode-I tahun 2017 kepada pihak Direktorat Penelitian dan Pengabdian kepada Masyarakat (Direktorat PPM) Universitas Telkom. Keputusan hasil evaluasi dan biaya yang disetujui untuk proposal tersebut diumumkan pada tanggal 13 April 2017 dengan nomor pengumuman 007/ABDI3/BPM/2017, yang juga diumumkan pada alamat tautan berikut: http://ppm.telkomuniversity.ac.id/wpcontent/uploads/2017/04/007-2017- pengumuman-hasil-evaluasi-PkM-1-Multiyears.pdf

Hasil keputusan DPPM inilah yang menghasilkan buah pikir berikutnya, yakni dalam konteks menciptakan identitas baru dengan konsep nama Tim S.A.R, yang merupakan akronim dari Sisca, Astri, Ratna). Seperti yang lazim diketahui oleh publik, baik di Indonesia maupun pada tataran internasional, istilah dalam wujud akronim SAR (Search And Rescue) adalah mencerminkan segala kegiatan dan usaha untuk mencari (search) dan menyelamatkan (rescue) jiwa manusia yang berada dalam berbagai keadaan bahaya. Dan lebih jauh lagi, Tim SAR juga sudah didefinisikan baku oleh Merriam-Webster, sebagaimana dinyatakan dalam kalimat berikut ini:

A group of people trained to find and help lost people (Merriam-Webster Incorporated, 2017).

Jika berangkat dari pola pikir bahwa nama adalah sebuah karakter atau uniqueness, maka dapat dipahami bahwa pemilihan identitas baru dengan konsep nama Tim S.A.R pada PkM ini tentunya tidak hanya identik dengan pemahaman yang sudah berlaku umum, namun sekaligus mengandung makna yang berbasis konsep yang kokoh sebagai landasan aktivitas Tim S.A.R dalam aktivitas PkM. Basis konsep kokoh tersebut adalah titik berangkat yang 
dapat dikelompokkan dalam skala lokal maupun skala global, yakni:

1) Titik berangkat dalam skala lokal, yakni bersumber dari pernyataan "tujuan" dan "isu strategis" oleh Direktorat PPM Universitas Telkom; yang artinya berbasis institusi perguruan tinggi di lingkungan negara Republik Indonesia. Hal ini secara jelas dinyatakan dalam Buku Panduan Pelaksanaan Pengabdian Kepada Masyarakat Dana Internal Universitas Telkom (DPPM Universitas Telkom, 2016:7), sebagaimana tertulis:

Tujuan butir no.2,

2. Menjadi agen kemajuan bangsa dan dunia serta turut serta dalam menjaga kelestarian budaya bangsa dan lingkungan dunia (sustainable development).

Isu strategis

Beberapa isu yang berkembang dewasa ini adalah environmental sustainability dan renewable energy. Kedua isu tersebut menjadi fokus utama penelitian di Universitas Telkom, untuk menghasilkan produk-produk yang secara langsung maupun tidak langsung dapat mengurangi efek kerusakan lingkungan dan peningkatan peluang penemuan sumber energi terbarukan, maka program pengabdian pada masyarakat idealnya adalah mengejawantahkan dan mengimplementasikan hasil-hasil dari riset/penelitian ini untuk menjadi solusi real di masyarakat dalam memecahkan dan menyelesaikan permasalahan yang ada terkait isu-isu sentral yang berkembang.

2) Titik berangkat dalam skala global, yakni bersumber dari pemahaman akan tantangan bangsa Indonesia untuk dapat mencapai tujuan dalam Sustainable Development Goals (SDGs). Sebagaimana yang sudah lazim dipublikasikan pada media cetak maupun media elektronik, negara-negara di dunia sekarang menyepakati sebuah platform baru dengan terminologi baru, yakni SDGs. Ada 17 poin penting di dalam SDGs, yakni terciptanya dunia dengan: (1) tanpa kemiskinan; (2) tanpa kelaparan; (3) kesehatan yang baik dan kesejahteraan; (4) pendidikan berkualitas; (5) kesetaraan gender; (6) air bersih dan sanitasi; (7) energi bersih dan terjangkau; (8) pertumbuhan ekonomi dan pekerjaan yang layak; (9) industri, inovasi, dan infrastruktur; (10) pengurangan kesenjangan; (11) keberlanjutan kota dan komunitas; (12) konsumsi dan produksi yang bertanggung jawab;

(13) aksi terhadap iklim; (14) kehidupan bawah laut; (15) kehidupan di darat; (16) institusi peradilan yang kuat dan kedamaian; dan (17) kemitraan untuk mencapai tujuan. Ke-17 poin penting tersebut juga sudah diilustrasikan sebagaimana yang ditampilkan pada gambar berikut ini.
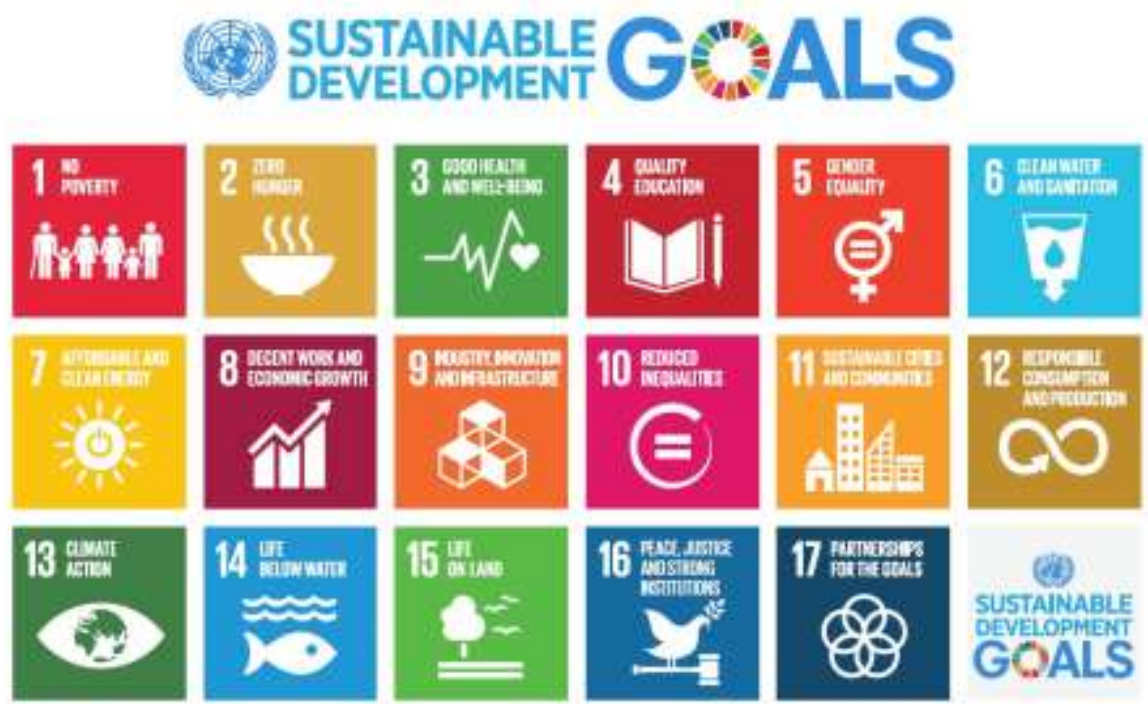

Gambar-1

17 poin penting Sustainable Development Goals (SDGs) 
Dari uraian titik berangkat yang berskala lokal dan global tersebut, maka tentunya dapat dipahami bahwa upaya PkM yang dilakukan oleh Tim S.A.R dalam wujud rintisan pembuatan bank sampah berbasis kelompok Rumah Tangga (RT) di RW-05 Kelurahan Cipaganti, Kecamatan Coblong, Kota Bandung ini adalah merupakan wujud hadirnya "tujuan" dan "isu strategis" Direktorat PPM Universitas Telkom sekaligus juga wujud hadirnya konsep SDGs, khususnya poin (4), poin (11) dan (17).

\section{RUMUSAN MASALAH}

Dari hasil evaluasi kegiatan sosialisasi bank sampah sekaligus tukar sampah jadi sembako pada tanggal 17 Januari 2017, diperoleh informasi dari Seksi Lingkungan Hidup RW05 Kelurahan Cipaganti bahwa:

1) adanya ketidakpuasan dari sebagian warga yang tidak memperoleh kesempatan untuk hadir pada acara sosialisasi bank sampah pada tanggal 17 Januari 2017;

2) terdapat 8 RT yang berpotensi menjadi nasabah komunal bank sampah;

3) belum pernah ada inisiatif dari pihak perguruan tinggi untuk membuat program edukasi tentang bank sampah di lingkungan RW-05 Kelurahan Cipaganti.

Di samping itu, Tim S.A.R juga melakukan observasi lapangan dan melakukan pertemuan- pertemuan dengan para warga. Dari observasi dan pertemuan tersebut, beberapa masalah yang dapat diidentifikasi adalah sebagai berikut:

1) belum adanya pemahaman akan potensi nilai ekonomi sampah yang dihasilkan setiap hari dari kegiatan rumahtangga;

2) belum tampak wujud nyata semangat "from trash to cash" atau "dari sampah menjadi berkah";

3) belum adanya pemahaman tentang bank sampah berbasis kelompok RT.

\section{METODE PELAKSANAAN PENGABDIAN MASYARAKAT}

Berangkat dari identifikasi masalah, maka selanjutnya Tim S.A.R melakukan metode pelaksanaan PkM sebagai berikut:

1) melaksanakan sosialisasi lanjutan yang bertahap pada tiap RT;

2) melaksanakan edukasi pemilahan sampah yang bertahap pada tiap RT;

3) melaksanakan rintisan pembuatan bank sampah berbasis kelompok RT.

Untuk kegiatan pada butir 1) dan 2), sudah dilaksanakan sejak bulan Mei 2017 sampai saat ini, yakni bulan November 2017, yakni dalam wujud:

1) membentuk nasabah kelompok berbasis RT;

2) kesepakatan bersama tentang identitas nama nasabah kelompok, yaitu Cihampelas Mandiri;

3) setor-timbang sampah anorganik yang dilaksanakan setiap hari Selasa, pada minggu ke-2 di tiap bulan berjalan;

4) rapat evaluasi dalam wujud pertemuan dan diskusi, pada minggu ke-3 di tiap bulan berjalan;

Sedangkan untuk butir 3) masih mengalami kendala yang disebabkan satu dan lain hal, di antaranya:

1) kajian mendalam tentang bank sampah dengan mengacu kepada Peraturan Mentri Lingkungan Hidup No.13 tahun 2012, tentang Pedoman Pelaksanaan Reduce, Reuse dan Recycle melalui Bank Sampah;

2) belum ada koordinasi yang matang dan mendalam antara Tim S.A.R dengan pihak Kecamatan Coblong;

3) aspek sarana dan pra-sarana lainnya yang masih memerlukan kajian lebih lanjut. 


\section{ANALISIS dan PEMBAHASAN HASIL KEGIATAN PENGABDIAN MASYARAKAT}

Berikut ini adalah uraian yang menjelaskan acara sosialisasi bank sampah sekaligus tukarsampah jadi sembako yang telah dilaksanakan pada tanggal 17 Januari 2017. Penjelasan berikut adalah dengan pendekatan " $5 \mathrm{~W}+1 \mathrm{H}$ ", yakni: apa (What), mengapa (Why), di mana (Where), kapan (When), siapa (Who) dan bagaimana (How).

\section{a) Apa (What)}

Sosialisasi bank sampah sekaligus tukar sampah jadi sembako di RW-05 Kelurahan Cipaganti di Kota Bandung adalah suatu kegiatan untuk merubah pola pikir masyarakat tentang sampah. Perubahan pola pikir dari perilaku membuang sampah tanpa memilah menjadi pola pikir memilah sampah untuk mendapat berkah. Sampah yang sudah dipilah berpotensi untuk menjadi tabungan di bank sampah dan tentunya dapat menambah penghasilan rumah tangga.

\section{b) Mengapa (Why)}

1. Memahami bahwa adanya persoalan pengelolaan sampah di Indonesia yang sampai sekarang belum ditemukan solusi yang menyeluruh.

2. Memahami bahwa hampir semua kota di Indonesia tetap tidak mampu mengatasi permasalahan pengelolaan sampah secara tepat dan berkelanjutan.

3. Mencermati fakta bahwa sampah yang dihasilkan oleh 2,4 juta penduduk Kota Bandung dari berbagai aktivitas di lingkungan rumah tangga, institusi, kantor, rumah sakit, sekolah maupun kampus, adalah berkisar antara $1.500 \sim 1.600$ ton sampah per hari.

4. Mencermati fakta bahwa adanya perkiraan $150 \sim 250$ ton sampah berceceran di sungai dan sudut kota. Keberadaan sampah tersebut mencemari sedikitnya 10 sungai di Kota Bandung.

5. Memahami bahwa tingginya produksi sampah dari penduduk Kota Bandung yang belum diimbangi dengan pengelolaan ideal, sehingga menambah beban Pemerintah Kota Bandung.

6. Keprihatinan Tim PkM Fakultas Ekonomi dan Bisnis (FEB) Universitas Telkom terhadap fenomena munculnya julukan "Bandung Lautan Api" yang kerap diplesetkan menjadi "Bandung Lautan Sampah".

7. Memahami bahwa di tengah minimnya pemilahan sampah yang dilakukan oleh warga Kota Bandung, maka dikhawatirkan akan berpotensi memicu kerusakan lingkungan.

8. Memahami bahwa lingkungan RW-05 Kelurahan Cipaganti di Kota Bandung yang berlokasi di bantaran sungai Cikapundung belum pernah dilaksanakan sosialisasi bank sampah.

Berangkat dari pemikiran dan kondisi faktual inilah kemudian muncul inisiatif kolaborasi antara Forum Gemricik, Tim PkM FEB Universitas Telkom, Bank Sampah Bersinar (BSB), Komunitas Kehkel RW-05, Karang Taruna unit RW-05; untuk bergerak, bertindak dan terpanggil untuk mengingatkan kembali tentang pentingnya pola pikir memilah sampah melalui kegiatan sosialisasi bank sampah sekaligus tukar sampah jadi sembako di RW05 Kelurahan Cipaganti di Kota Bandung.

c) Di mana (Where)

Bertempat di Masjid Mungsolkanas RW-05 Kelurahan Cipaganti di Jl.Cihampelas, Bandung.

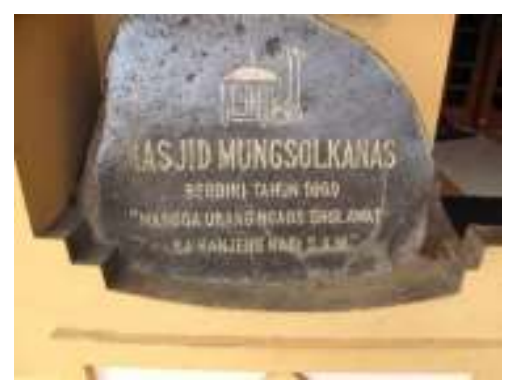




\section{d) Kapan (When)}

Telah dilaksanakan pada tanggal 17 Januari 2017 dengan penulisan kombinasi angka 17.01.17 yang ditampilkan pada spanduk dan pin berikut sebagai wujud identitas PkM.
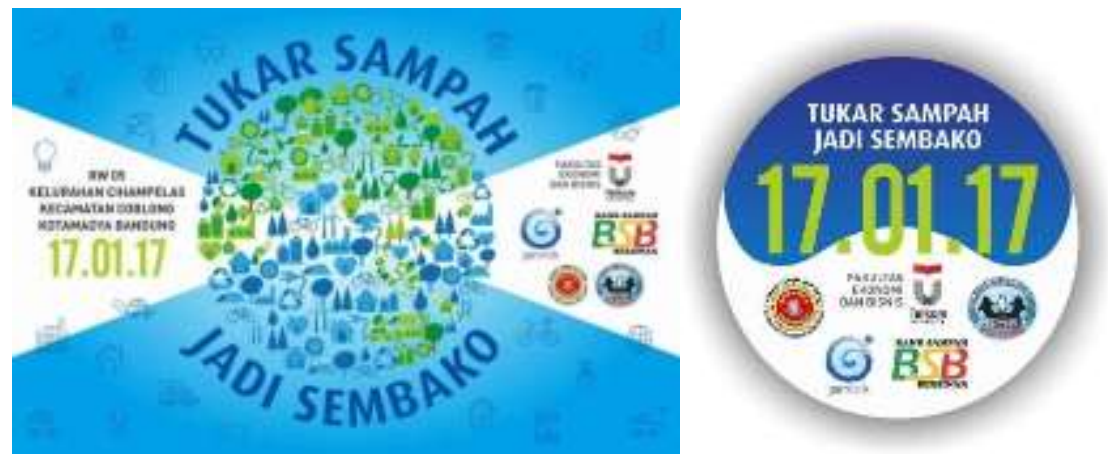

e) Siapa (Who)

1. Penyelenggara acara sosialisasi ini dilakukan oleh Panitia yang berangkat dari semangat peduli dan cinta lingkungan bersih dan sehat. Panitia ini adalah wujud kolaborasi 5 elemen masyarakat, yakni: 1) Tim PkM FEB Universitas Telkom, dengan identitas nama Tim S.A.R (akronim dari Sisca, Astri, Ratna); 2) Forum Gerakan Masyarakat Cinta Cikapundung (Gemricik); 3) Bank Sampah Bersinar (BSB); 4) Komunitas Kehkel RW-05 Cihampelas; 5) Karang Taruna Unit RW-05 Cihampelas.

2. Peserta sosialisasi bank sampah adalah warga Kelurahan Cipaganti, seluruh pengurus dan anggota Forum Gemricik, para Dosen dan mahasiswa dari Kelompok Keahlian (KK) bidang ilmu Entrepreneurship, FEB Universitas Telkom, perwakilan Dosen dari Fakultas Seni Rupa dan Desain (FSRD) Universitas Kristen Maranatha, perwakilan Greeneration Indonesia, Komunitas Cikapundung KEHKEL.

\section{f) Bagaimana (How)}

1. Dalam menyelenggarakan kegiatan sosialisasi ini, Panitia bekerjasama dan bermitra dengan warga Rw-05 Kelurahan Cipaganti, yang terdiri dari 8 kelompok RT.

2. Rencana kegiatan disosialisasikan melalui serangkaian pertemuan, baik di Sekretariat Gemricik maupun di Balai Warga RW-05 Kelurahan Cipaganti sejak bulan November 2016 dan juga melalui spanduk maupun brosur.

Untuk lebih memahami urgensi kegiatan PkM tentang rintisan pembuatan bank sampah berbasis kelompok Rumah Tangga (RT) di RW-05 Kelurahan Cipaganti, Kecamatan Coblong, Kota Bandung ini, maka berikut ini ditampilkan peta lokasinya.

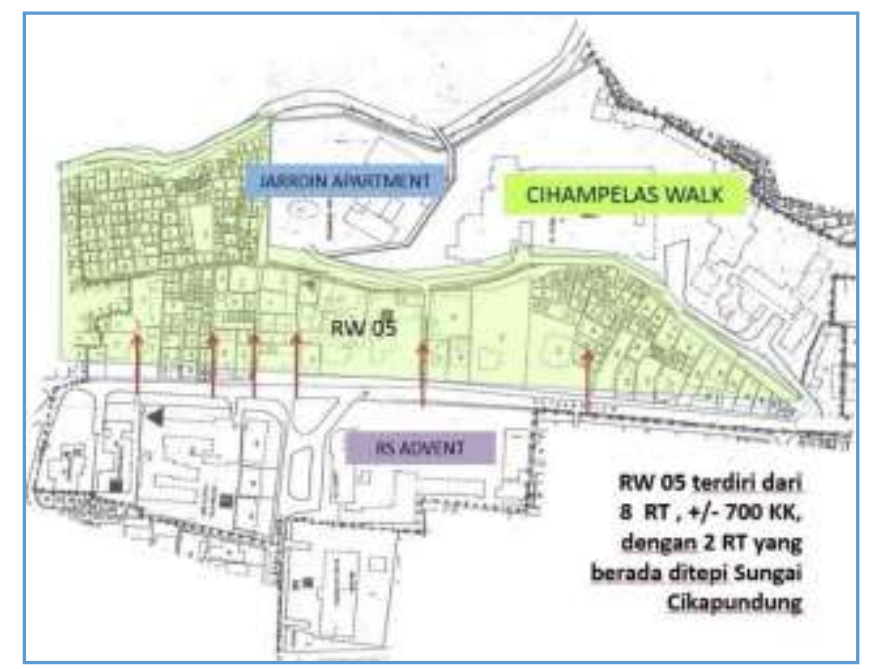




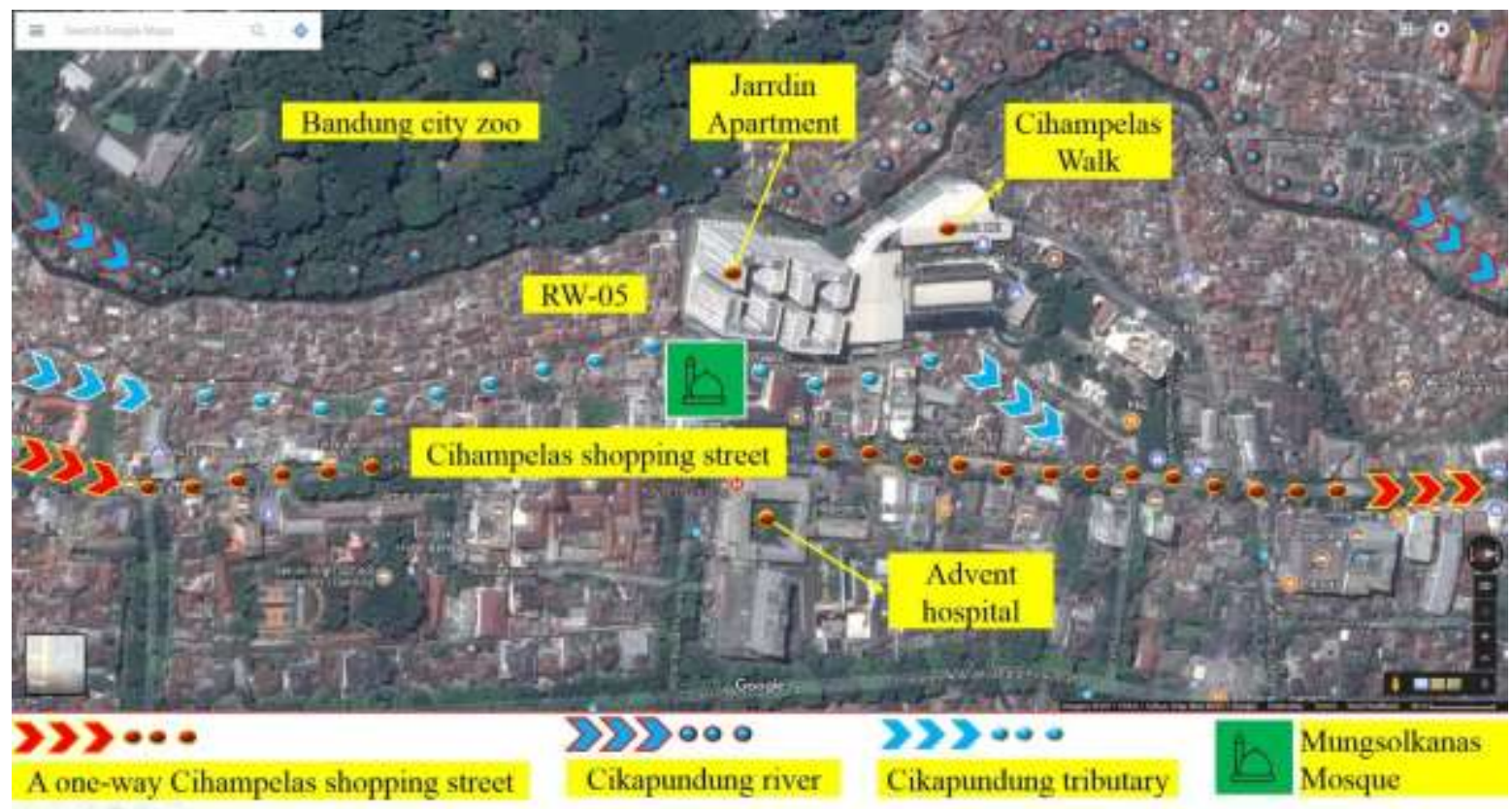

Gambar-2

Lokasi RW-05 Kelurahan Cipaganti, Kecamatan Coblong, Kota Bandung

Dari tampilan gambar-2 diperoleh informasi beberapa hal berikut ini:

1) lingkungan pemukiman RW-05 yang padat dan diapit oleh sungai Cikapundung dan jalan Cihampelas;

2) tanda panah berwarna merah adalah akses jalan masuk ke lingkungan RW-05 dari arah Jl. Cihampelas, yang keseluruhannya berjumlah 6 (enam) akses masuk berupa gang kecildengan lebar kurang lebih 1,5 m;

3) terdapat 2 (dua) RT yang berada di bantaran sungai Cikapundung, yang lokasinya bertetangga dengan Jarrdin Apartment;

4) terdapat 700 Kepala Keluarga (KK) dari total 8 RT.

Untuk dapat mengukur berapa jumlah potensi perekonomian warga yang berangkat dari semangat "from trash to cash" atau "dari sampah menjadi berkah", maka dapat dilakukan perhitungan yang sederhana, sbb:

1) jika diperkirakan produksi sampah mencapai 0,5 - 0,8 kilogram $(\mathrm{kg}) / \mathrm{KK} / \mathrm{hari}$, maka volume sampah dari $700 \mathrm{KK}$ bisa mencapai $350 \mathrm{~kg} / \mathrm{hari}$; dengan perhitungan sederhananya adalah = $700 \mathrm{KK} \times 0,5 \mathrm{~kg} / \mathrm{hari}$;

2) dari jumlah $350 \mathrm{~kg} / \mathrm{hari}$ tersebut, jika diasumsikan yang dapat ditampung di Tempat Pemrosesan akhir (TPA) hanya 40\% - 50\% saja, maka masih ada tersisa $175 \mathrm{~kg} / \mathrm{hari}$ yang belum ditampung di TPA dan tersebar di lingkungan RW-05 Kel.Cipaganti;

3) kemudian jika diasumsikan bahwa nilai sampah anorganik yang sudah terpilah dengan baik adalah minimum berkisar Rp.5.000,-/kg, maka diperoleh angka Rp. 875.000,-/hari yang terbuang percuma $(175 \times 5.000=875.000)$;

4) maka nilai ekonomi yang terbuang selama 1 tahun $=365 \times$ Rp. 875.000,- $=$ Rp. 319.375.000,(Tigaratus sembilan belas juta, tigaratus tujuhpuluh lima ribu rupiah) untuk $700 \mathrm{KK}$.

Tentunya nilai Rp. 319.375.000._ yang diperoleh selama 1 tahun akan sangat bermanfaat jika dapat dikelola dengan baik untuk kesejahteraan bersama di lingkungan RW05 Kelurahan Cipaganti ini. Dana ini juga dapat untuk membangun fasilitas umum untuk aktivitas kebersamaan warga. Dari kondisi-kondisi inilah, maka dapat dipahami bahwa warga di lingkungan RW-05 Kelurahan Cipaganti memiliki potensi yang besar untuk meningkatkan perekonomian dari semangat "from trash to cash" atau "dari sampah menjadi berkah". 
Di sisi lain, potensi yang besar ini juga dapat bertambah dengan adanya beberapa sumber penghasil sampah anorganik di sekitar lingkungan RW-05 Kelurahan Cipaganti, yakni sebagai berikut:

1) Jl.Cihampelas yang dikenal sebagai wisata belanja dan saat ini sudah memiliki "Skywalk" Cihampelas;

2) terdapat beberapa lembaga pendidikan;

3) Rumah Sakit Advent;

4) Apartemen Jarrdin Cihampelas;

5) Cihampelas Walk.

Penting untuk diuraikan pada tulisan ini, akan manfaat bank sampah yang dikaitkan dengan peningkatan perekonomian masyarakat, sebagaimana yang ditampilkan pada kliping berikut ini.

\section{BANK SAMPAH DORONG PENINGKATAN PEREKONOMIAN MASYARAKAT} BANDUNG RAYA Selasa, 17 Januari 2017|19:11 WIB

Bank sampah diharapkan dapat meningkatkan perekonomian warga, mengingat setiap sampah yang dibuang memiliki nilai ekonomis. Namun demikian sejauh ini pandangan masyarakat menilai bahwa sampah adalah sumber penyakit dan bencana.

Direktur Bank Sampah Bersinar, John Sumual mengatakan bahwa perlu adanya sosialiaasi kepada masyarakat dalam membuka wawasan terhadap bank sampah. Sehingga dapat mengubah perilaku masyarakat terhadap sampah dengan cara yang bersahabat dan menguntungkan.

"Kita sosialisasi tahap pengenalan kepada pengurus RW dan RT, kita hadirkan langsung mengenai konsep bank sampah. Sehingga sampah yang dibuang dapat menjadi uang dan yang paling penting bagaimana mengubah masyarakat dalam memperlakukan sampah," ungkapnya usai sosialisasi bank sampah di Mesjid Mungsolkanas, RT 01 RW 05, Kelurahan Cipaganti , Kecamatan Coblong, Kota Bandung, Selasa (17/1/2017). Menurutnya target dari kegiatan tersebut ke depannya, warga Kota Bandung akan menjadi pemilah sampah yang baik. Mengingat yang berminat kepada bank sampah bukan hanya dari kalangan menengah ke bawah tapi juga menengah ke atas, karena selain menambah kebersihan juga mendidik anakanak untuk lebih peduli lingkungan.

Program yang merupakan kolaborasi dari Gerakan Masyarakat Cinta Cikapundung (Gemricik), Bank Sampah Bersinar (BSB), Telkom University, Komunitas Kehkel RW 05 dan Karang Taruna RW 05 tersebut, sangat penting dalam melibatkan masyarakat. Terlebih cara yang digunakan selama ini masih konvensional sehingga nilai ekonomis dari sampah hilang begitu saja. "Cara memperlakukan sampah di masyarakat saat ini masih konvensional, sehingga sampah terbuang begitu saja tanpa ada manfaat yang bisa diambil. Tapi dengan uang sebagai daya tarik untuk mereka diharapkan dapat menumbuhkan kesadaran tersebut," tuturnya.

Pada kesempatan yang sama, Ketua Gemricik, Ratna L. Nugroho menilai kendala dari program tersebut yakni edukasi kepada masyarakat. Terutama pada kaum Ibu-ibu yang setiap hari bergulat dengan sampah rumah tangga. "Kami disini sebagai motor penggerak Ibu-bu yang setiap hari bergaul dengan sampah rumah tangga. Mereka kita edukasi agar dapat memilah mana sampah yang bernilai ekonomis, karena mereka membawa sampah harus dalam keadaan bersih kepada bank sampah," katanya.

Ratna menerangkan bahwa potensi sampah yang berada di area tersebut sangat besar, sebab berada di kawasan industri sehingga dapat diolah oleh warga. Ditambah dengan warga yang berada di RW tersebut mencapai 700 kepala keluarga. Walau demikian, program tersebut saat ini baru menerima sampah anorganik walaupun tidak menutup kemungkinan ke depan dengan adanya sampah organik. "Kita juga menyayangkan setiap sampah rumah tangga yang dibuang berpotensi minimal 10 ribu, tentu hal tersebut tanpa disadari. Oleh karena itu, kita edukasi masyarakat agar dapat menyadari potensi yang ada dari sampah yang setiap hari dihasilkan," tambahnya. 
Sementara itu, salah seorang warga sekitar, Wiwi Kurniawati (46) merespon positif keberadaan bank sampah bersinar di lingkungannya. Sehingga sampah harian yang dihasilkan dapat membantu perekonomian keluarga. "Tentu respon baik karena dapat membantu perekonomian keluarga. Selain itu, lebih disiplin sehingga tidak membuang sampah sembarangan yang membuat lingkungan tercemar," ujarnya.

Sumber: http://www.galamedianews.com/index.php?menu=bandung-

raya\&id=131352\&judul=bank-sampah- dorong-peningkatan-perekonomian-masyarakat (diakses 1 Februari 2017)

Pendapat warga yang diliput oleh salah satu media cetak pada bulan Januari 2017 tersebut dapat dikaitkan dengan hasil setor timbang sampah, sebagaimana yang ditampilkan pada tabel berikut.

\begin{tabular}{|c|c|c|c|c|c|c|c|c|}
\hline \multirow{2}{*}{$\begin{array}{c}\text { Jadwal setor- } \\
\text { timbang } \\
\text { tahun } 2017\end{array}$} & \multicolumn{8}{|c|}{ Nilai Rupiah Tabungan Nasabah Kelompok Cihampelas Mandiri (CM) } \\
\hline & \begin{tabular}{l|l}
1 \\
\end{tabular} & 2 & \begin{tabular}{l|l}
3 & \\
\end{tabular} & 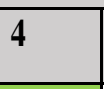 & 5 & 6 & 7 & 8 \\
\hline $11 \& 14$ Juli & 83.130 & 72.940 & 7.700 & - & 38.740 & 15.230 & 259.900 & 31.350 \\
\hline $8 \& 11$ Agustus & 91.580 & 59.260 & 28.890 & - & 40.730 & 88.780 & 186.010 & 21.180 \\
\hline 5 September & 108.630 & 190.500 & 69.770 & 10.740 & 68.370 & - & 170.750 & 33.350 \\
\hline 10 Oktober & 254.375 & 205.885 & 83.840 & - & 18.550 & - & 230.560 & 127.290 \\
\hline Total & 537.715 & & 190.200 & 10.740 & 166.390 & 104.010 & 847.220 & 213.170 \\
\hline
\end{tabular}

Dengan mengacu kepada tabel tersebut, dapat dipahami bahwa terjadi fluktuasi nilai rupiah pada tiap nasabah kelompok. Selain itu, nasabah CM-4 dan CM-6 belum berpartisipasi aktif sepenuhnya dalam aktivitas setor-timbang. Untuk itu kepada para pengurus CM-4 dan CM-6 diajak aktif kembali dalam aktivitas setor timbang yang ke-5.

\section{KESIMPULAN dan SARAN}

Dalam konteks PkM berupa rintisan pembuatan bank sampah berbasis kelompok Rumah Tangga (RT) di RW-05 Kelurahan Cipaganti, Kecamatan Coblong, Kota Bandung ini, maka tentunya dapat dirangkum beberapa butir kesimpulan, yakni:

1) kegiatan sosialisasi bank sampah sekaligus tukar sampah jadi sembako pada tanggal 17 Januari 2017 yang dilakukan oleh Tim S.A.R adalah merupakan wujud hadirnya aspek sustainable development; yang merupakan tujuan dari Direktorat PPM Universitas Telkom;

2) sosialisasi lanjutan dan edukasi pemilahan sampah pada tiap RT adalah merupakan upaya untuk terus membangun kepedulian masyarakat agar dapat memiliki pola pikir untuk mendapatkan manfaat ekonomi langsung dari sampah;

3) aktivitas setor-timbang yang dilakukan setiap bulan adalah mata rantai yang saling berkaitan dan tidak boleh putus dengan aktivitas rapat evaluasi, sebab terjadi fluktuasi nilai rupiah pada tiap nasabah kelompok.

Sesuai dengan potensi yang dapat digali dari aktivitas setor-timbang sampah di lingkungan RW-05 Kelurahan Cipaganti dan juga sekaligus edukasi untuk merintis pembuatan bank sampah, maka berikut adalah saran yang diajukan kepada pihak Direktorat PPM Universitas Telkom:

1) melanjutkan dukungan untuk kegiatan PkM Tim S.A.R agar lingkungan RW-05 Kelurahan Cipaganti mampu menjadi role model bagi RW yang lain di Kecamatan Coblong;

2) memfasilitasi kegiatan PkM Tim S.A.R dalam wujud lintas perguruan tinggi;

3) memfasilitasi kegiatan PkM Tim S.A.R untuk diangkat ke tingkat inovasi sosial dalam lingkup Kementrian Ristek Dikti. 


\section{DAFTAR PUSTAKA}

Merriam-Webster Incorporated. (2017). Search and rescue team. [Online]. Diunduh dari https://www.merriam-webster.com/dictionary/search\%20and\%20rescue\%20team [5 November 2017]

DPPM Universitas Telkom. (2016). Buku Panduan Pelaksanaan Pengabdian Kepada Masyarakat Dana Internal Universitas Telkom Tahun 2016. Diunduh dari http://ppm.telkomuniversity.ac.id/wpcontent/uploads/2016/07/Panduan-Abdimas-2016- 21072016-fix.pdf [31 Desember 2016]

\section{FOTO KEGIATAN}

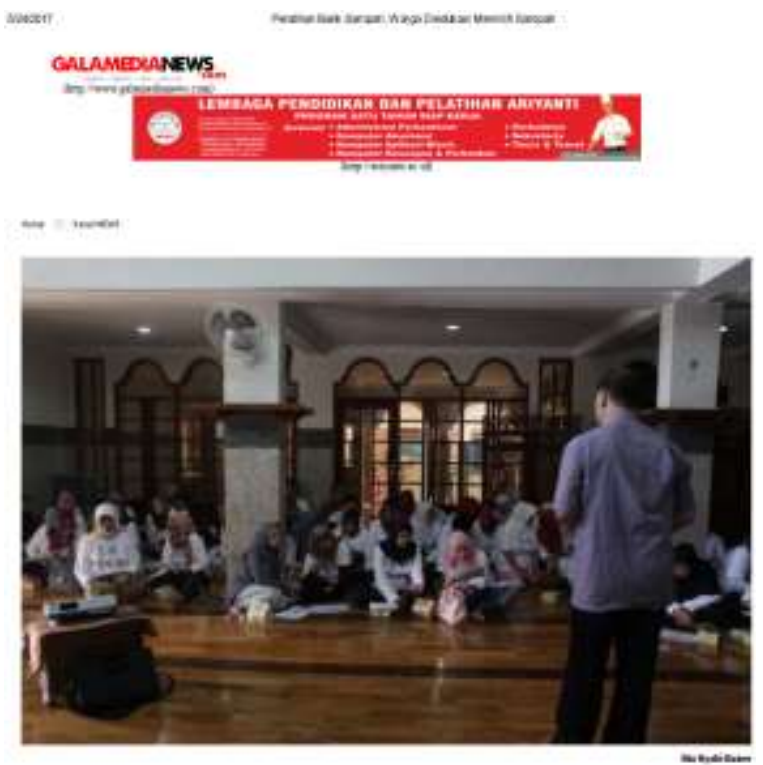

Pelatihan Bank Sanquah, Warga Qiedakasi Hemilith Samoah

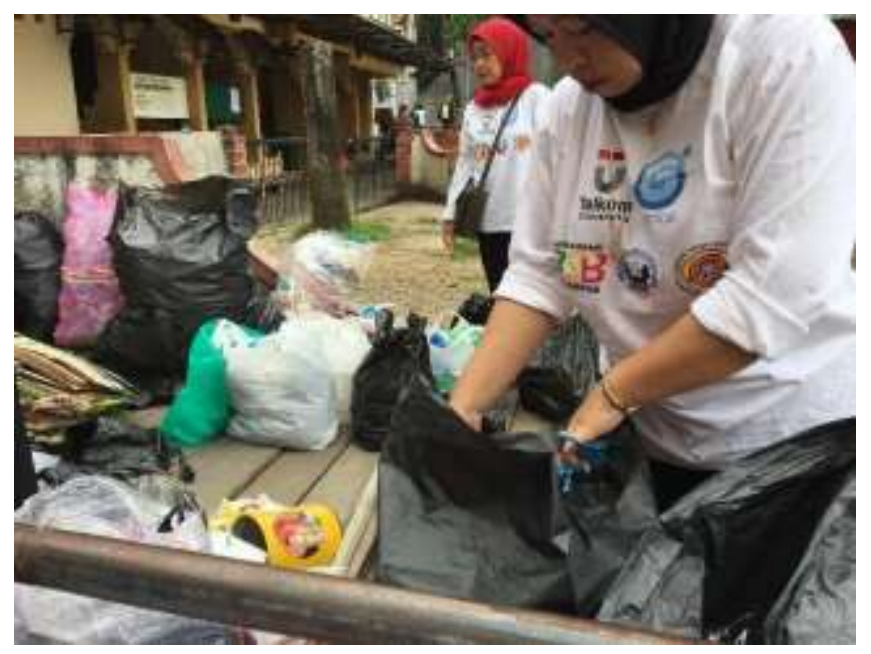

Alamat tautan video singkat setor-timbang yang sudah dilaksanakan adalah sbb: https://www.facebook.com/Gemricik-163281357059377/ 


\section{BIODATA SINGKAT Tim S.A.R}

\begin{tabular}{|c|c|c|}
\hline Nama & Biodata singkat & Tanggal ijazah \\
\hline $\begin{array}{l}\text { Sisca Eka } \\
\text { Fitria (S) }\end{array}$ & $\begin{array}{l}\text { Research area: } \\
\text { Entrepreneurship, Marketing Bisnis Media } \\
\text { Educational background: } \\
\text { M.M. (Universitas Padjadjaran) } \\
\text { S.T. (Universitas Bung Hatta) } \\
\text { Google scholar: siscaekafitria@ @elkomuniversity.ac.id }\end{array}$ & $\begin{array}{l}\text { S1 } \\
\text { S2 }\end{array}$ \\
\hline $\begin{array}{l}\text { Astri } \\
\text { Ghina (A) }\end{array}$ & $\begin{array}{l}\text { Research area: } \\
\text { Entrepreneurship, Corporate Entrepreneurship } \\
\text { Educational background: } \\
\text { Dr. (School of Business and Management, Institut Teknologi Bandung) } \\
\text { M.S.M. (School of Business and Management, Institut Teknologi Bandung) } \\
\text { S.SI (Universitas Padjadjaran) } \\
\text { Google scholar: astrighina@telkomuniversity.ac.id }\end{array}$ & $\begin{array}{l}\text { S1 (2002) } \\
\text { S2 (2011) } \\
\text { S3 (2015) }\end{array}$ \\
\hline $\begin{array}{l}\text { Ratna } \\
\text { Lubis } \\
\text { Nugroho } \\
\text { (R) }\end{array}$ & $\begin{array}{l}\text { Research area: } \\
\text { Entrepreneurship, Ecopreneurship, Sociopreneurship, Small Business } \\
\text { Management, New Venture Management, Strategic Management } \\
\text { Educational background: } \\
\text { - Dr. (Universitas Pendidikan Indonesia) } \\
\text { - M.M. (Asian Institute of Management, Manila-Philippines) } \\
\text { - Ir. (Teknik Arsitektur, Institut Teknologi Bandung) Google scholar: } \\
\text { ratnalnugroho@telkomuniversity.ac.id }\end{array}$ & $\begin{array}{l}\text { S1 } \\
\text { S2 } \\
\text { S3 }\end{array}$ \\
\hline
\end{tabular}

